Western University Scholarship@Western

Centre for the Study of International Economic

Centre for the Study of International Economic

Relations Working Papers

Relations

1984

\title{
On the Determination of External Debt: The Case for Israel
}

Zvi Hercowitz

Follow this and additional works at: https://ir.lib.uwo.ca/economicscsier_wp

Part of the Economics Commons

Citation of this paper:

Hercowitz, Zvi. "On the Determination of External Debt: The Case for Israel." Centre for the Study of International Economic Relations Working Papers, 8439C. London, ON: Department of Economics, University of Western Ontario (1984). 
ISSN $\quad 0228-4235$

ISBN $\quad 0-7.714-0583-9$

THE CENTRE FOR THE STUDY OF INTERNATIONAL ECONOMIC RELATIONS

WORKING PAPER NO. 8439C

ON THE DETERMINATION OF THE EXTERNAL DEBT:

THE CASE FOR ISRAEL

Zvi Hercowitz

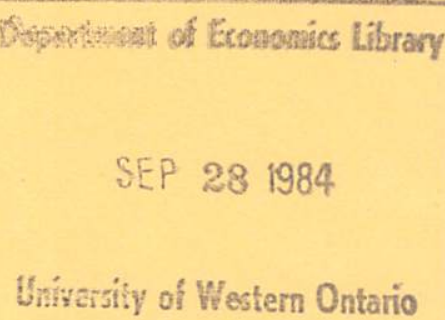

This paper contains preliminary findings from research work still in progress and should not be quoted without prior approval of the author.

DEPARTMENT OF ECONOMICS

THE UNIVERSITY OF WESTERN ONTARIO

LONDON, CANADA

N6A 5 C 2 
ON THE DETERMINATION OF THE EXTERNAL DEBT:

THE CASE OF ISRAEL

By: Zvi Hercowitz

Tel-Aviv University

and

University of Western Ontario

Revised September 1984

I thank Alex Cukierman, David Elkayam, Jeremy Greenwood, Levis Kochin, Leo Leiderman, Assaf Razin and two anonymous referees for helpful discussions and comments. I also thank Yaakov Lavie and Oded Liviatan for providing part of the data used in this research. Financial support from the P. Sapir Center for Development, Te1-Aviv University is gratefully acknowledged. 


\section{INTRODUCTION}

Israel's net foreign debt at the end of 1981 was 13.1 billion U.S. dollars, which represents a per-capita burden of about 3,300 dollars. The aim of this paper is to investigate whether the development of this debt can be explained by an equation derived from an intertemporal maximization framework under perfect capital markets. The model used here is a simple version of the type of framework studied recently by Bruno (1982), Dornbusch (1983), Sachs (1981, 1982), and Svensson and Razin (1982, 1983).

In this model the private sector maximizes utility from consumption over an infinite horizon subject to an intertemporal budget constraint which recognizes the intertemporal finance equation of the government - - in other words, the "Ricardian equivalence theorem" is incorporated. Under these conditions, the effect of current disturbances in output, government spending, and so forth, on private consumption decisions is determined by their perceived future persistence. The higher the latter, the stronger the impact of the shock on perceived wealth and hence on current consumption. From the national income accounts, this implies that the effect of the shock on the capital account will be negatively related to its persistence.

The model also predicts that holding all shocks at their zero levels, the foreign debt will follow a path which, in general, depends on the interest rate, the economy's growth rate, and the parameters of the utility function. If these parameters are such that the optimal constant growth of planned consumption equals the economy's growth rate (an assumption that was adopted) the foreign debt will also grow at that rate. Thus, this 
set-up does not generate a long-run ratio of foreign debt to GNP. This ratio will remain at the historical initial level unless it is disturbed by exogenous shocks. This outcome is similar to Barro's (1979) result regarding the long-run public debt.

An important additional variable in the case of Israel is the unilateral transfers to the private sector, and, especially, to the government. These transfers have a direct effect on the capital account and also an indirect effect, via the intertemporal budget constraints of the two sectors. The importance of the public transfers is especially evident during the war years of 1967 and 1973, when real government spending went up by about 1/3 of the respective previous years' levels. The increase in the volume of these transfers in 1967 represents about $2 / 3$ of the increment in government expenditures; the comparable figure for 1973 is 1. These large inflows of transfers seem related to the phenomenon that the real foreign debt actually declined in 1973, and increased only slightly in 1967.

The transfers come from world Jewry and friendly governments - mainly from West Germany until 1965, and from the United States since the early 1970s. The model incorporates a simple equation for the determination of the unilateral transfers to the government. The basic assumption about these transfers is that they are associated with the financial needs of the Israeli public sector. They are positively related to government spending, particularly abnormal expenditures, and to the variations in private income as a measure of taxation capacity. The perceived future path of these transfers 
is therefore related to the expected persistence of the shocks affecting their levels. The transfers to the private sector were included in the private income variable since a satisfactory model describing their determination is not available.

The empirical implementation of the model requires the estimation of the exogenous processes driving the economy -- that is, government expenditures and an income variable -- and the transfers equation. The main purpose of this stage of the empirical analysis is to estimate the degree of persistence of the exogenous variables. The model is then formally tested by confronting the coefficients of the foreign debt equation with the values that can be expected given the parameters of the processes estimated previously.

I I. THE MODEL

In this section an equation is derived for the external debt growth of a small economy. The external real debt, $Z$, is composed by the government's debt, $Z^{g}$, and the privately held debt, $z^{p}$.

The basic framework for discussing the foreign debt growth comes from the national income accounts. Ignoring investment in this section, the identity between output and its uses in the present period (one) is

$$
G_{1}+C_{1}=G P_{1}+I M_{1}-E X_{1}
$$

where $G$ is government spending, $C$ is private consumption, GDP is gross domestic product, and IM-EX is excess imports of goods and services. 
From the balance of payments it follows that

$$
I M_{1}-E X_{1}=T_{1}^{p}+T_{1}^{g}+Z_{1}-(1+r) Z_{0}
$$

where $T^{p}$ and $T^{g}$ are unilateral transfers to the private and public sectors respectively and $r$ is the constant, exogenously given, real interest rate. Substituting this equality into (1) and defining the gross private income variable $\mathrm{Y} \equiv \mathrm{GDP}+\mathrm{T}^{\mathrm{P}}$ yields

$$
\mathrm{Z}_{1}-\mathrm{Z}_{0}=\mathrm{C}_{1}+\mathrm{G}_{1}-\mathrm{Y}_{1}-\mathrm{T}_{1}^{\mathrm{g}}+\mathrm{rZ}_{0}
$$

This equation expresses the equality between the surplus in the capital account on the one hand, and the difference between total absorption $\left(C_{1}+G_{1}\right)$ and GNP plus total unilateral transfers $\left(Y_{1}-r Z_{0}+T_{1}^{g}\right.$ $=\operatorname{GDP}+\mathrm{rZ}_{0}+\mathrm{T}_{1}^{\mathrm{p}}+\mathrm{T}_{1}^{\mathrm{g}}$ ) on the other.

To analyze the effects of temporary movements of output and government spending, it is assumed that $Y$ and $G$ grow at a common normal rate, $\mu$, with current deviations from trend levels which are known to be serially correlated. Specifically, the current levels of $Y$ and $G$, and their expected future paths are

$$
Y_{t}=P_{1}(1+\mu)^{t-1}\left(1+n \lambda{ }^{t-1}\right), \quad G_{t}=G_{1}(1+\mu)^{t-1}\left(1+\varepsilon_{\rho}{ }^{t-1}\right), \quad t=1,2, \ldots,
$$

where $0 \leq \lambda \leq 1$ and $0 \leq \rho \leq 1$. The fractions $n$ and $\varepsilon$ represent the current deviations from trend of income and government spending respectively. The speed at which each variable is expected to return to its trend level in the future is determined by the parameters $\lambda$ and $\rho$. The common normal growth rate implies a long-run constant $G / Y$ ratio. 
We proceed now to the determination of private consumption demand. The model used here assumes certainty about the future path of the exogenous variables. Hence, the optimization problem solved below is deterministic. 1 The representative individual maximizes an intertemporal utility function over an infinite horizon, subject to an intertemporal budget constraint. Assuming a time-separable logarithmic utility function, the individual's optimization problem is

$$
\begin{aligned}
& \operatorname{Max} \sum_{t=1}^{\infty} \frac{U\left(C_{t}\right)}{(1+\delta)^{t-1}}=\sum_{t=1}^{\infty} \frac{\log C_{t}}{(1+\delta)^{t-1}} \text {, subject to } \\
& \sum_{t=1}^{\infty} \frac{C_{t}}{(1+r)^{t-1}}=\Sigma_{t=1}^{\infty} \frac{Y_{t}-\tau}{(1+r)^{t-1}}+(1+r)\left(b_{0}-z_{0}^{P}\right)=W_{1},
\end{aligned}
$$
where $\tau_{t}$ is taxes paid in period $t, b$ is the private holdings of government bonds, and $W_{1}$ is current net wealth of the private sector. For $W_{1}$ to be finite, it is necessary to assume that $r>\mu$.

The standard solution of this problem is:

$$
\begin{aligned}
& \text { (4a) } c_{1}=\frac{\delta}{1+\delta} W_{1}, \text { and } \\
& \text { (4b) } \quad c_{t}=c_{1}\left(\frac{1+r}{1+\delta}\right)^{t}, \quad t=2,3, \ldots
\end{aligned}
$$

Current consumption is proportional to wealth, and it is planned to grow at the rate $(1+r) /(1+\delta)$. The solution would not be altered if government spending were included additively in the utility function. Under a more general specification marginal utility from consumption and hence consumption levels would be affected by $G$. 
In general, the rate of consumption growth can be either higher or lower than the rate of income growth, depending on the values of the interest rate and the time preference parameter. In principle, therefore, the consumptionincome ratio could approach zero, or alternatively, infinity. The se extreme outcomes are ruled out only under the assumption that $(1+r) /(1+\delta)=1+\mu$. In this case consumption grows at the normal growth rate of output. The adoption of this simplifying assumption amounts to a restriction on the permissible values of the parameters $\delta, \mu$ and $r$. Although this assumption is arbitrary in the present context, it can be justified as an equilibrium condition under a simple structure of the world economy. Assume that the world is composed of a large number of countries, identical to the home country in all respects (in particular, the parameters $\delta$ and $\mu$ are the same everywhere) but in the current deviations of the exogenous variables from trend and in the outstanding foreign debts. Across countries, those deviations average to zero and the foreign debts cancel out. For the sake of simplicity in this argument, assume no unilateral transfers. Now, given the growth rate, $\mu$, of total output and governments' spending, worldwide dynamic equilibrium requires an equal growth rate of world consumption. This is achieved bnly when the real interest rate adjusts such as to satisfy $1+r=(1+\delta)(1+\mu)$. This condition also assures worldwide equilibrium in period one. $^{2,3}$ Given this condition, current consumption in (4a) is determined as

$$
c_{1}=\frac{r-\mu}{1+r} w_{1}
$$

The next step is the calculation of $W_{1}$. Given the intertemporal budget constraint of the government, the present value of taxes is: 


$$
\sum_{t=1}^{\infty} \frac{\tau_{t}}{(1+r)^{t-1}}=\Sigma_{t=1}^{\infty} \frac{G_{t}-T_{t}^{g}}{(1+r)^{t-1}}+(1+r)\left(b_{0}+z^{g}\right)
$$

The introduction of the outstanding total debt of the government (internal and external) in (6) implicitly rules out the possibility of perpetual debt finance. Substituting (6) into the wealth expression yields:

$$
W_{1}=\sum_{t=1}^{\infty} \frac{Y_{t}-G_{t}+T_{t}^{g}}{(1+r)^{t-1}}-(1+r) Z_{0}
$$

Wealth depends on the $Y_{t}-G_{t}+T_{t}^{g}$ flows and on the private and public external debts added up. The internal debt cancels out.

Consider now the unilateral transfers to the public sector. These transfers affect the capital account--equation (2)--directly, as well as Indirectly, via the intertemporal budget constraint of the government, which is internalized by the private sector. The modeling of these transfers attempts to capture their nature in the case of Israe1. The basic presumption, because of their source, is that they are motivated by the financial needs of the government. They are thus assumed to be positively related to government spending, especially extraordinary expenditures, and negatively to income fluctuations, as a measure of the current taxation capacity. It is assumed that this relationship takes the form:

$$
T_{1}^{g}=a_{1} \bar{G}_{1}+a_{2} \varepsilon \bar{G}_{1}+a_{3} \eta \bar{Y}_{1}+\xi, 1>a_{2}>a_{1}>0, a_{3}<0,
$$

where $\xi$ is a transitory disturbance with a serial correlation coefficient $\omega$. Hence, the expected pattern of future transfers to the public sector is:

$$
T_{t}^{g}=a_{1} \bar{G}_{1}(1+\mu)^{t-1}+a_{2} \bar{G}_{1}(1+\mu)^{t-1} \varepsilon \rho^{t+1}+a_{3} \bar{Y}_{1}(1+\mu)^{t-1} \eta \lambda^{t-1}+\xi \omega^{t-1} .
$$


Since (8) is believed to hold at all times, transfers in the future are expected to reflect the persistence of the disturbances in government spending and income.

Given the time pattern of $Y, G$, and $T^{g}$, and solving the present value expressions, perceived net wealth can be expressed as:

$$
\text { ( } \left.7^{\prime}\right) \quad W_{1}=\frac{1+r}{r-\mu}\left[\bar{Y}_{1}-\left(1-a_{1}\right) \bar{G}_{1}\right]+\frac{(1+r)\left(1+a_{3}\right)}{1+r-(1+\mu) \lambda} y-\frac{(1+r)\left(1-a_{2}\right)}{1+r-(1+\mu) \rho} g+\frac{1+r}{1+r-w} \xi-(1+r) z_{0}
$$

where $\mathrm{y} \equiv \eta \overline{\mathrm{Y}}_{1}$ and $\mathrm{g} \equiv \mathrm{e}_{\mathrm{G}}$.

Substituting $\left(7^{\prime}\right)$ into (5) yields the current consumption level as a function of the exogenous variables and the out standing foreign debt:

$$
C_{1}=\bar{Y}_{1}-\left(1-a_{1}\right) \bar{G}_{1}+\frac{(r-\mu)\left(1+a_{3}\right)}{1+r-(1+\mu) \lambda} y-\frac{(r-\mu)\left(1-a_{2}\right)}{1+r-(1+\mu) \rho} g+\frac{r-\mu}{1+r-\omega} g-(r-\mu) Z_{0} .
$$

To obtain the growth of the external debt, equations (8) and (9) and the expressions $Y_{1}=\bar{Y}_{1}+y$, and $\bar{G}_{1}=G_{1}+g$ are substituted into (2) to yield: (10) $z_{1}-z_{0}=\frac{(1+\mu)(1-\rho)\left(1-a_{2}\right)}{1+r-(1+\mu) \rho} g-\frac{(1+\mu)(1-\lambda)\left(1+a_{3}\right)}{1+r-(1+\mu) \lambda} y-\frac{1+\mu-\omega}{1+r-\omega} \xi+\mu z_{0}$.

Foreign debt growth is affected positively by government spending shocks and negatively by income fluctuations. The systematic components of income and government spending drop out, because their direct effect is fully offset by an opposite effect on private consumption. The independent part of the public transfers, $\xi$, has a negative effect on foreign borrowing. The transfers that are explained by $g$ and $y$ are taken into account in their coefficients by $a_{2}$ and $a_{3}$. Given these parameters, the magnitudes of the coefficients of $g$ and $y$ depend on their corresponding serial correlations. The higher $\rho$, for example, the larger the increase in the present value of taxes following a positive g. Correspondingly, a large downward adjustment in consumption 
follows, resulting in a smaller effect on the capital account. When $\rho=1$, $g$ is permanent and therefore it drops out, similar to the systematic component $\bar{G}_{1}$. At the other extreme, when $\rho=0$, the shock is purely transitory. In this case the coefficient of $g$ gets its highest possible value: $(1+\mu)\left(1-a_{2}\right) /(1+r)$, which is lower than 1 by assumption. Hence the coefficient of $g$ in (10) is between 0 and 1 . The coefficient of the income fluctuations is negative because consumption adjusts by less than the income shift, so that a positive $y$ is followed by positive private savings. The higher the persistence parameter $\lambda$, the greater the net wealth and the corresponding consumption adjustments, resulting in a smaller negative effect on the capital account.

The magnitude of the coefficients of $g$ and $y$ decline with the magnitude of the parameters $a_{2}$ and $a_{3}$. Namely, the sensitivity of the public transfers to movements in these variables dampens their effects both on private net wealth--and hence on consumption--and on foreign borrowing. The transfers disturbance affects the debt growth according to their perceived persistence. ${ }^{4}$

The last term in equation (10) is $\mu Z_{0}$, which says that holding spending and output at trend levels, the foreign debt grows at the same rate as the economy. That is, this model does not generate a normal or optimal foreign debt or foreign-debt - income ratio. The outstanding debt is never amortized. It stays at the initial level unless it is altered by exogenous disturbances. This characteristic of the model is the same as that in Barro's (1979) analysis of the behavior of the public debt. In Barro's model it is the smoothing of the tax-income ratios that generates the unamortized government debt. In the present model a similar role is played by the smoothing of consumption levels. 
This undetermined movement of the foreign debt has a natural upward limit, which is the future ability of the country to pay the debt. Current foreign debt cannot exceed $\sum_{t-1}^{\infty}\left(Y_{t}-G_{t}+T_{t}^{g}\right) /(1+r)^{t-1}$, which is equivalent to saying that net wealth, and hence consumption, cannot be negative. ${ }^{5}$

\section{EMPIRICAL IMPLEMENTATION}

To test the hypotheses presented in the previous section, the following procedure has been adopted. First, a way to incorporate investment in the empirical analysis is discussed. Then, the government spending, the income, and the public transfers processes are estimated. This part of the analysis also provides proxies for the different disturbances affecting the foreign debt. Next, the empirical counterpart of the foreign debt growth equation (10) is discussed and estimated. Here the coefficients are expected to conform to the values that can be calculated given the estimates of the normal growth rate, the parameters of serial correlation, and the coefficients of the public transfer process.

\section{a. Treatment of Investment}

Although the determination of investment is not discussed in this paper, its correlation with the included variables makes it empirically desirable to incorporate investment in the analysis. The compromise adopted in this respect is as follows. 
Total gross capital formation, I, is composed of gross investment of private firms, $I^{p}$, and public gross investment, $I^{g}$. Correspondingly, private net wealth is now computed as

$$
W_{1}=\sum_{t=1}^{\infty} \frac{Y_{t}-I_{t}^{p}-\tau_{t}}{(1+r)^{t-1}}+(1+r)\left(b_{0}-Z_{0}^{p}\right) .
$$

To see that the relevant before-tax income flow is $Y-I^{P}$, assume that the firms finance $I^{p}$ from retained earnings. Then, labor income and dividends (plus private unilateral transfers) equal $Y$ net of private investment. The overall budget constraint of the government is now

$$
\sum_{t=1}^{\infty} \frac{\tau_{t}}{(1+r)^{t-1}}=\sum_{t=1}^{\infty} \frac{G_{t}+I_{t}^{g}-T_{t}^{g}}{(1+r)^{t-1}} .
$$

Substituting (12) into the private wealth expression yields

$$
W_{1}=\sum_{t=1}^{\infty} \frac{Y_{t}-I_{t}-G_{t}+T_{t}^{g}}{(1+r)^{t-1}}-(1+r) Z_{0},
$$

which differs from the original wealth expression in equation (7) by the appearance of $-I_{t}$ in the capitalized flows. If the government receives income directly from its owned capital, a corresponding term should appear in the numerator of the right-hand side of (12) with negative sign. In this case, the income variable in (11) would be private income only. However, after the substitution of (12), private income and public income from production add up again to $Y_{t}$, which was defined as GDP plus private transfers. 
To proceed with the analysis, the notion of "net income" is defined as $Y^{\prime}=Y-I$, which appears both in the private wealth expression and in the national income accounting. ${ }^{6}$ It is assumed that $Y^{\prime}$ also grows normally at the rate $\mu$, with a current serially-correlated deviation from the trend of $y^{\prime}$. Equations (8), (9), and (10) hold again with $y^{\prime}$ substituted for $y$. However, to simplify the notation, the "I" is dropped in the following discussions.

b. Public Spending, Net Income and Transfers to the Private Sector

Before proceeding with the empirical analysis, it should be pointed out that the data on the relevant variables is available partly in constant shekels and partly in United States dollars. Hence, prior to the econometric work it is necessary to express all data in the same, constant price units. For this it is necessary to assume purchasing power parity. The assumption used is that $p_{t}=e_{t} p_{t}^{*}$, where $p_{t}$ is the Israeli GDP deflator, $e_{t}$ is the effective exchange rate (on exports) of the U.S. dollar, and $\mathrm{p}_{\mathrm{t}}^{*}$ is "the". U.S. dollar price level. All data are converted into 1975 shekels by multiplying the U.S. dollar figures by $e_{t}$ and dividing by $p_{t} \cdot 7$

The empirical formulation of the public spending and net income patterns specified in the previous section is

(14) $\log G_{t}=\alpha+\mu t+\varepsilon_{t}$

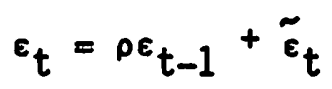

(15) $\log Y_{t}=\beta+\mu t+\eta_{t}$

$n_{t}=\lambda n_{t-1}+\tilde{n}_{t}$, 
where the growth rate $\mu$ is constrained to be the same in both equations, and $\tilde{\varepsilon}_{t}$ and $\tilde{\mu}_{t}$ are normally distributed innovations.

The data used in the estimation of (14) and (15) are annual real

consumption of the public sector, gross domestic product, gross domestic capital formation, and unilateral transfers to the private sector. All these variables, except the unilateral transfers, are available in 1975 shekels. The transfers are converted into the same units as previously mentioned.

Public consumption includes all defense expenditures, including those that could be thought of as investment. The unilateral transfers to the private sector include personal transfers, (bequests, gifts, and personal transfers) and restitution payments and pensions from West Germany. ${ }^{8}$ The importance of these transfers relative to the GDP changed during the sample. It ranges from about 1 percent to 10 percent of GDP, with an average of about 6 percent.

Equations (14) and (15) are estimated simultaneously using a nonlinear procedure, and imposing the same normal growth rate across equations. The estimates are:

$$
\begin{aligned}
& \log G_{t}=6.33+0.056 t \text {, } \\
& \text { (0.59) (0.016) } \\
& \hat{p}=0.90 \quad \text { D.W. }=2.15 \text {, }
\end{aligned}
$$


(15')

$$
\begin{aligned}
& \log Y_{t}=7.20+0.056 t \text {, } \\
& (0.51) \quad(0.016) \\
& \hat{\lambda}=0.88 \\
& \text { D.W. }=2.41 \text {, }
\end{aligned}
$$

sample 1953-1981, 9

where the standard errors appear in parentheses below the corresponding estimates.

The normal growth rate of the economy is estimated at 5.6 percent, and the long run $G / Y$ ratio is 0.42 . The estimated equations display a significant degree of positive serial correlation. Using the estimates of $\rho$ and $\lambda$ it is possible to calculate the "average persistence" of the shocks, i.e., the number of years that a disturbance would have to remain at the same level (and then drop to zero) to make the present value of the deviations from trend equal to that under the asymptotic decline. Assuming that $r$ is 6.5 percent -- which has to be assumed higher than 5.6 percent -- the average persistence of government spending shocks is about 10 years and that of output is about 8 years. 10

Normal levels of government spending and net income are

$$
G_{t}=\exp (\alpha+\mu t), \quad P_{t}=\exp (\beta+\mu t),
$$

and correspondingly, the deviations from normal are 


$$
g_{t}=G_{t}-\bar{G}_{t}, \quad y_{t}=Y_{t}-P_{t}
$$

The empirical equation for the unilateral transfers to the public sector follows directly from the previous section:

$$
T_{t}^{g}=a_{1} \bar{G}_{t}+a_{2} g_{t}+a_{3} y_{t}+\xi_{t}, \xi_{t}=\omega \xi_{t-1}+\xi_{t}
$$

The data on $\mathrm{T}^{\mathrm{g}}$ includes the intergovernmental transfers, transfers from world Jewry, and donations to nonprofit organizations. These data are available from 1952 onwards, and consistently constructed only through 1980. In this series, transfers from the United States government were registered at the time of arrival of the imports that the Israeli government purchased with them. This is the same timing as that of the inclusion of these imports in the national accounts, and hence it seems suitable for this study."

$$
\text { Using as explanatory variables the series of } G_{t}, g_{t} \text {, and } y_{t} \text { obtained }
$$
above, the estimated transfers equation is

$$
\begin{aligned}
& T_{t}^{g}=\begin{array}{ll}
0.27 \bar{G}_{t}+0.47 g_{t}-0.18 y_{t} \\
(0.03) \quad(0.13) \quad(0.15)
\end{array} \\
& R^{2}=\begin{array}{lll}
0.80 & \hat{\omega}=0.39 & \text { D.W. }=1.86
\end{array}
\end{aligned}
$$


The signs of the coefficients conform to the expectations, although the coefficient of $y$ is insignificantly different from zero. Fluctuations in government spending affect public transfers with the sizable coefficient of 0.47 , which means that almost half of these expenditures are financed by transfers. The coefficient of $G_{t}$ indicates that the long-run ratio of public transfers to government spending is 0.27 .

Finally, the estimates of $\xi_{t}$ are obtained as the residuals of $\left(16^{\prime}\right)$.

c. Foreign Inflation and the Empirical Debt-Growth Equation

The model used in the previous section does not include foreign inflation, which is also relevant for the determination of the real value. of the external debt. Here, anticipated and unanticipated foreign inflation are incorporated, and an empirical counterpart of equation (10) is specified.

In this discussion, the problem that the data are available in different currencies is assumed away for convenience by pretending that all data are expressed in U.S. dollars. Consider now the nominal counterpart of equation (2)

$$
Z N_{t}=\ldots+\left(1+i_{t}\right) Z N_{t-1}
$$

where $Z N$ is the foreign debt in dollars, the dots represent the dollar value of $C_{t}+G_{t}-Y_{t}-T_{t}^{g}$, and $i_{t}$ is the annual nominal interest rate pertinent to the outstanding debt. The value of $i_{t}$ is viewed as averaging the relevant past interest rates that took into account different inflationary expectations. 
Maintaining the assumption of a constant real interest rate, the nominal rate can be expressed as

$$
1+i_{t}=(1+r)\left(1+\pi_{t}^{e}\right)
$$

where $\pi_{t}^{e}$ is the relevant "average" past expectation regarding the rate of change in the dollar price level from year $t-1$ to year $t$. Defining $\tilde{\pi}_{t}$ as the residual unexpected inflation, $p_{t}^{*}$ can be written as:

$$
p_{t}^{*}=p_{t-1}^{*}\left(1+\pi_{t}^{e}\right)\left(1+\tilde{\pi}_{t}\right) \text {. }
$$

Substituting (17) into (2'), deflating by $p_{t}^{*}$ from (18), and rearranging terms yields:

$$
\frac{Z N_{t}}{p_{t}^{\star}}-\frac{Z N_{t-1}}{p_{t-1}^{\star}}=\ldots+r \frac{Z N_{t-1}}{p_{t-1}^{\star}}-(1+r) \frac{Z N_{t-1}}{p_{t-1}^{\star}}\left(\frac{\tilde{\pi}_{t}}{1+\tilde{\pi}_{t}}\right) .
$$

This modified version of equation (2) includes an additional random term on the right-hand side, indicating a direct negative effect of unexpected inflation on the real foreign debt.

To obtain the corresponding counterpart of the final equation (10) consider the private wealth which, expressed in constant dollars, now includes the term:

$$
-\frac{(1+r) Z N_{t-1}}{p_{t-1}^{*}\left(1+\tilde{\pi}_{t}\right)}=-\frac{(1+r) Z N_{t-1}}{p_{t-1}^{*}}+\frac{(1+r) Z N_{t-1}}{p_{t-1}^{*}}\left(\frac{\tilde{\pi}_{t}}{1+\tilde{\pi}_{t}}\right),
$$


instead of $-(1+r) z_{0}$ in equation ( $\left.7^{\prime}\right)$. Namely, private wealth now contains an additional random term which represents the positive effect of unanticipated foreign inflation. Correspondingly, the consumption equation here includes the term

$$
-(r-\mu) \frac{Z N_{t-1}}{p_{t-1}^{*}}+(r-\mu) \frac{Z N_{t-1}}{p_{t-1}^{*}}\left(\frac{\tilde{\pi}_{t}}{1+\tilde{\Pi}_{t}}\right)
$$

in place of $-(r-\mu) z_{0}$ in equation (9). Substituting the modified consumption equation into $\left(2^{\prime \prime}\right)$ yields

$$
\frac{Z N_{t}}{p_{t}^{*}}-\frac{Z N_{t-1}}{p_{t-1}^{*}}=\ldots+\mu \frac{Z N_{t-1}}{p_{t-1}^{*}}-\frac{(1+\mu) Z N_{t-1}}{p_{t-1}^{*}}\left(\frac{\tilde{\pi}_{t}}{1+\tilde{\pi}_{t}}\right),
$$

where the dots represent the sum of the constant dollars value of $g, y$, and $\xi$ multiplied by the corresponding coefficients.

In the resulting debt-growth equation expected inflation does not appear because it affects the nominal interest rate and the current price level equally. With respect to the effect of unanticipated inflation - the last term of the equation -- the econometric procedure adopted in this paper will treat it as a residual. This seems appropriate under the following

considerations. Given that $\tilde{\pi}_{t}$ is an unanticipated magnitude, it is reasonable to assume that it has zero mean and

that it is uncorrelated with $Z N_{t-1} / p_{t-1}^{\star}$. Also, since the variance of $\tilde{\pi}_{t}$ can be considered small compared to 1 , the variation of $\tilde{\pi}_{t} /\left(1+\tilde{\pi}_{t}\right)$ can be assumed to closely replicate the movements of $\tilde{\pi}_{t}$. Under these assumptions, the last term in $\left(10^{\prime}\right)$ can be treated as uncorrelated with the explanatory variables, especially with $\mathrm{ZN}_{t-1} / \mathrm{p}_{t-1}^{*}$. 

Using the equality $p_{t}^{*}=p_{t} / e_{t}$ and defining $Z_{t} \equiv Z N_{t} \cdot e_{t} / p_{t}$ and $v_{t} \equiv(1+\mu) z_{t-1} /\left[\tilde{\Pi}_{t} /\left(1+\tilde{\Pi}_{t}\right)\right]$, equation (10') is written in its empirical form:

(19) $z_{t}-z_{t-1}=b_{1} g_{t}+b_{2} y_{t}+b_{3} \xi_{t}+b_{4} z_{t-1}+v_{t}$.

Given the estimates of $\rho, \lambda, \mu, \omega, a_{2}$, and $a_{3}$, and assuming again that $r=0.065$ the predictions about the coefficients of (19) are

$$
\begin{aligned}
& b_{1}=\left(1-\hat{a}_{2}\right) 0.92=0.49 \\
& b_{2}=-\left(1+\hat{a}_{3}\right) 0.94=-0.77 \\
& b_{3}=-0.99 \\
& b_{4}=\hat{\mu}=0.056 .
\end{aligned}
$$

Public spending and net income have similar degrees of persistence. Hence, the smaller magnitude of the former's coefficient follows primarily from the stronger effect of $g$ on public transfers.

The concept of $Z N$ used in the estimation of (19) is Israel's net liabilities. It includes the short-and the long-term foreign debt of the private and public sectors, net of Israel's foreign assets. The latter includes the reserves at the Bank of Israel and other monetary institutions and private foreign deposits and securities. These data are available from 1955 onwards. 
The estimated equation is

$$
\begin{aligned}
& z_{t}-z_{t-1}=\underset{(0.19)}{0.54 g_{t}}-\underset{(0.20)}{0.39} y_{t}-1.34 \xi_{t}+\underset{(0.32)}{\left(0.041 z_{t-1}\right.}(0.022) \\
& R^{2}=0.56 \quad \text { D.W. }=1.46 \quad \hat{\sigma}=286.2,
\end{aligned}
$$

sample 1956-1980,

where $\hat{\sigma}$ is the standard error of the equation.

The estimates of the coefficients are all significantly different from 0 at the 5 percent level, and those of $g$ and $\xi$ at the 1 percent level. However, the test of the model does not involve the null hypothesis, but whether the estimated coefficients conform to the values predicted. The estimates of $b_{1}, b_{3}$, and $b_{4}$ are not far from those values, but the magnitude of the coefficient of $y$ is only of about half that expected. Namely, variations in net income are implied to have a stronger effect on consumption than that predicted by the theory, resulting in a low countercyclical foreign borrowing. Also, the only moderate $R^{2}$ can be seen, according to the theory, as reflecting an important role of unexpected foreign inflation in the determination of the debt growth.

The Durbin-Watson statistic indicates the possible presence of positive serial correlation, which is plausible under the interpretation given to the error term. The disturbances in this model follow from unanticipated 
inflation as of the "average" date on which the terms of the outstanding liabilities were set. If this date is further in the past than a year - as it probably is during the sample (see Liviatan (1980)) -- anticipated inflation can display serial correlation. However, reestimating the equation using the Cochrane-Orcutt procedure yields a coefficient of serial correlation that is insignificantly different from zero.

Equation (20) is only partially unrestricted because it involves the restriction of zero coefficients on the systematic components of the exogenous variables. The unrestricted estimation will also include some combination of these components, since they are perfectly colinear among themselves. This combination can be $P_{t}-\left(1-a_{1}\right) \mathbb{G}_{t}$, which is the permanent income type of variable that enters the consumption equation (9). This estimation is unrestricted in the sense that it involves all the exogenous variables with unrestricted coefficients. Including the trend variable the estimated equation is:

$$
\begin{aligned}
& (21) z_{t}-z_{t-1}=\underset{(0.21)}{0.55} g_{t}-\underset{(0.29)}{0.44} y_{t}-\underset{(0.41)}{10.40} \xi_{t}+\underset{(0.108)}{0.067} z_{t-1}-\underset{(0.114)}{-0.028}\left[\nabla_{t}-\left(1-a_{1}\right) G_{t}\right] . \\
& R^{2}=0.56 \quad \text { D.W. }=1.50 \quad \hat{\sigma}=292.9
\end{aligned}
$$

The coefficient of $P_{t}-\left(1-a_{1}\right) G_{t}$ is insignificantly different from 
zero as predicted, but now the coefficient of $Z_{t-1}$ becomes insignificant. If $z_{t-1}$ is deleted, the trend variable becomes significant. This seems to reflect a strong correlation between $z_{t-1}$, which is heavily trended, and $P_{t}-\left(1-a_{1}\right) G_{t}$. Also, the inclusion of the trend variable reduces the t-statistic associated with $y$ from 1.97 to $1.51 .^{12}$

The formal test of the model -- given the procedure used to estimate the preliminary equations -- is performed by imposing the predicted values to all the coefficients, amounting to five linear constraints. The corresponding $F_{20}^{5}$ statistic is 2.64 , which falls uncomfortably close to the corresponding 5 percent critical value of 2.71 . Hence, the model is almost rejected at the 5 percent confidence level. The main source of this outcome seems to be the high predicted value for the coefficient of the income variable.

Since the expected estimates were computed under the assumption of a real interest rate of 6.5 percent, a sensitivity analysis in this respect is in order. This was done by using two alternative values for $r$. Theoretically, admissible values should be higher than 5.6 percent. Hence, a lower $r$ was chosen as 6 percent, and the alternative higher value considered is 8 percent; still higher rates seem unplausible. When $r$ is 6 percent the resulting $F_{20}^{5}$ statistic is 2.77 , and for 8 percent it turns out to be 2.35. Therefore, the results do not change much in this exercise. However, higher interest rates make the results slightly improve the goodness-of-fit. It seems that this is because the magnitude of the computed coefficients decline with $r$. Since the major divergence occurs in the coefficient of $y$, which is expected to be twice as high, higher interest rates (at least in the 6-8 percent range), tend to improve the overall fit of the equation. 
IV. CONCLUDING REMARKS

This paper attempted the empirical implementation of an intertemporal optimization mode1 of the foreign debt with data on Israe1. As seen in the previous section, the results are in general inconclusive. The model is not far enough from rejection to conclude that the equation fits well the behavior of Israel's foreign borrowing.

The main problem seems to be that the predicted strong countercyclical behavior of the debt growth appears weaker in the data. This result can be viewed as stemming from a "too" strong procyclical, or Keynesian, behavior of private consumption, which partially offsets the negative effect of income on foreign borrowing. Given the dominant negative values of the income variable during the sample, one could say that if the private sector would have behaved according to this model the foreign debt would today be even larger than it actually is.

With respect to the other estimated coefficients, especially that of public expenditure, they are not very different from the values predicted. The difference between the results for government spending and the income variable could be related to different degrees of accessibility of the government and the private sector to the foreign capital markets - a factor that was not taken into account in the model. Capital controls may interfere with the private smoothening of consumption by foreign borrowing and lending, while the government is free from these constraints. An interesting analysis of the relevance of capital controls is carried out in Greenwood and Kimbrough (1984). The incorporation of this consideration is probably a promising extension of the type of framework studied here. 
The present analysis could also be extended in other directions. One is to use a time-series procedure to isolate transitory and permanent shocks instead of the present specification of the exogenous processes - adopted here because of its simplicity and the relatively smooth transition from the theory to the econometrics it facilitates. Another possible extension involves the incorporation of unexpected foreign inflation in the analysis, rather than leaving it as the residual. Unexpected inflation affects the real value of the foreign debt directly, and also indirectly via the private wealth and consumption demand. The implementation of this extension would require the study of the maturity composition of the outstanding debt during the sample and the estimation of the corresponding unexpected inflation series. 


\section{FOOTNOTES}

1. This, of course, presents the problem of using a deterministic model as the basis for empirical work. The reason for following this procedure is that it yields a simple closed form solution--suitable for econometric estimation in the sense that the endogenous variable depends on exogenous variables only. An alternative way to generate a similar certaintyequivalent solution is to specify stochastic exogenous variables under a quadratic utility function. For the present purposes, however, one does learn any additional insight by this route and hence $I$ believe that the additional complications involved are unwarranted.

2. To verify this, substitute the expression for $W_{1}$ as developed in ( $7^{\prime}$ ) into (5) and average across countries. Then all disturbances and the foreign debt terms drop out. Note that the parameter $a_{1}$ is assumed to be zero.

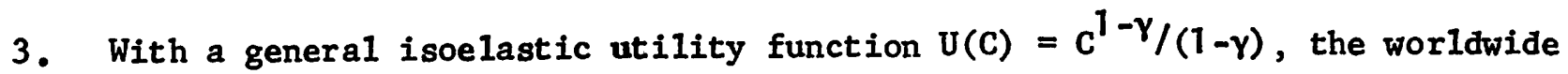
equilibrium condition would be $1+r=(1+\delta)(1+\mu)^{\gamma}$.

4. However, even when $w=1, \xi$ still has an effect on debt growth. This is so because the persistence of this disturbance was defined on its magnitude and not percentage from normal levels. Thus, a perfectly persistent transfer shift declines over time relative to income and government spending.

5. The interest rate that the country is subject to in the international capital markets would probably adjust upwards well before the foreign debt approaches the $\Sigma\left(Y_{t}-G_{t}-T_{t}^{g}\right) /(1+r)^{t-1}$ level. This possibility can be generalized by specifying that the relevant interest rate is a positive continuous function of $z_{t}$, relative to the future ability to pay. I tentatively explored the introduction of this specification 
into the present model in which the interest rate becomes endogenous. The main modification that follows is that shocks have a smaller effect on foreign borrowing, because a domestic savings reaction partially offsets the demand for funds generated by those shocks. Also, this setup seems to yield a long-run optimal foreign-debtincome ratio.

6. The corrected equation (2) is $Z_{1}-Z_{0}=C_{1}+G_{1}-\left(Y_{1}-I_{1}\right)-T_{1}^{g}+r Z_{0}$.

7. The effective exchange rate on exports was used because of its availability on the entire sample. It seems unlikely that the alternative use of the exchange rate on imports or some average of the two would affect the results.

8. Donations to nonprofit organizations that could be considered part of these transfers are included in the public transfers series. The reason for this is that the data prior to 1962 is available in this form, with no separate figures on nonprofit organizations.

9. The sample starts in 1953 because private transfers data is available only from 1952 onwards.

10. The calculation is made as follows. Taking public spending for example, the present value of the deviations from trend is

$$
\sum_{t=0}^{\infty} \frac{\bar{G}(1+\mu)^{t}\left(1+\varepsilon_{\rho}{ }^{t}\right)}{(1+r)^{t}}=\varepsilon \bar{G}\left[\frac{1+r}{1+r-(1+\mu)_{\rho}}\right] .
$$

If $\varepsilon$ fully persists $k$ years, the corresponding present value is

$$
\varepsilon \bar{G} \sum_{t=0}^{k-1}\left(\frac{1+\mu}{1+r}\right)^{t}=\varepsilon \bar{G}\left[\frac{1+r}{r-\mu}-\frac{(1+\mu)}{r-\mu}\left(\frac{1+\mu}{1+r}\right)^{k-1}\right] \text {. }
$$

The average persistence is now calculated by equating 
$-27-$

$$
\frac{1+r}{1+\mu}-\left(\frac{1+\mu}{1+\mu}\right)\left(\frac{1+\mu}{1+r}\right)^{k-1}=\frac{1+r}{1+r-(1+\mu)_{\rho}} \text {. }
$$

From this it follows that

$$
k=\log \left[\frac{(1+\mu)(1-\rho)}{1+r-(1+\mu) \rho}\right] / \log \left(\frac{1+\mu}{1+r}\right)
$$

11. In 1981 the timing of the registration of the transfers from the U.S. government was changed to a cash-flow basis. For example, if the Israeli government uses these funds to make a down payment on its imports, this payment is registered as a unilateral transfer at that time.

12. Including a constant in the equation the corresponding t-statistic is on ty 0.67 . 


\section{REFERENCES}

Barro, Robert J., "Are Government Bonds Net Wealth?", Journal of Political Economy, 82(6), November/December 1974. , "On the Determination of the Public Debt," Journal of Political Economy, 87(5) October 1979. Bruno, Michael, "Adjustment and Structural Change Under Raw Materials Price Shocks," Scandinavian Journal of Economics, 84(2), 1982. Dornbusch, Rudiger, "Real Interest Rates, Home Goods and Optimal External Borrowing," Journal of Political Economy, 91(1), February 1983.

Greenwood, Jeremy and Kent P. Kimbrough, "Capital Controls and the International Transmission of Fiscal Policy," unpublished manuscript, July 1984. Liviatan, Oded, "Israel's External Debt," Bank of Israel Economic Review, 48-49, May 1980.

Razin, Assaf and Lars E.0.Svensson, "The Current Account and the Optimal Government Debt," Journal of International Money and Finance, August 1983.

Sachs, Jeffrey D., "The Current Account and Macroeconomic Adjustment in the 1970's", Brookings Papers on Economic Activity, 1981:1. - "The Current Account in the Macroeconomic Adjustment

Process," Scandinavian Journal of Economics, 84(2), 1982.

Svensson, Lars E.0. and Assaf Razin, "The Terms of Trade and the Current Account: The Harberger-Laursen-Metzler Effect," Journal of Political Economy, 91(1), November, 1983. 
TABLE 1

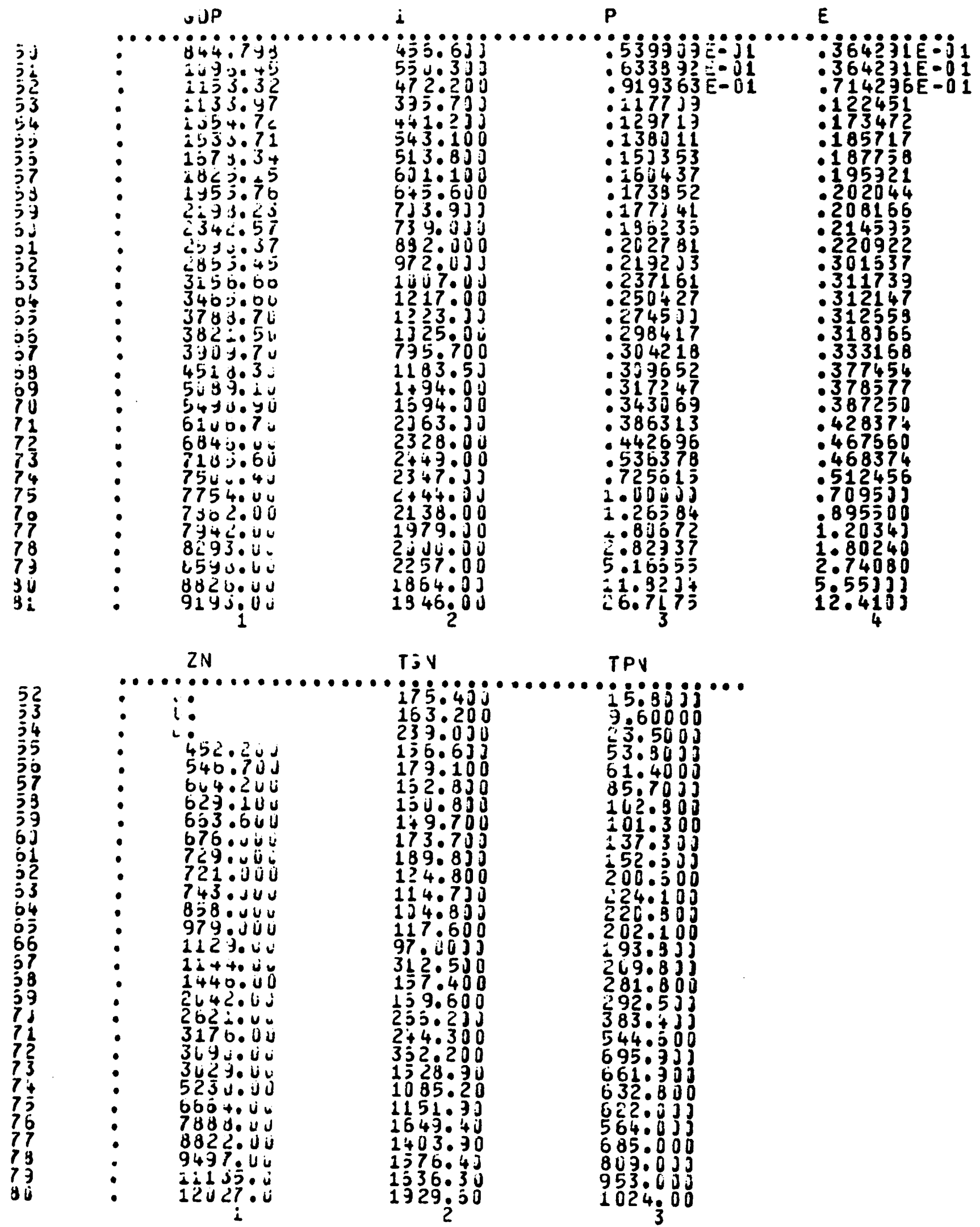




\section{TABLE 1 (Cont'd)}

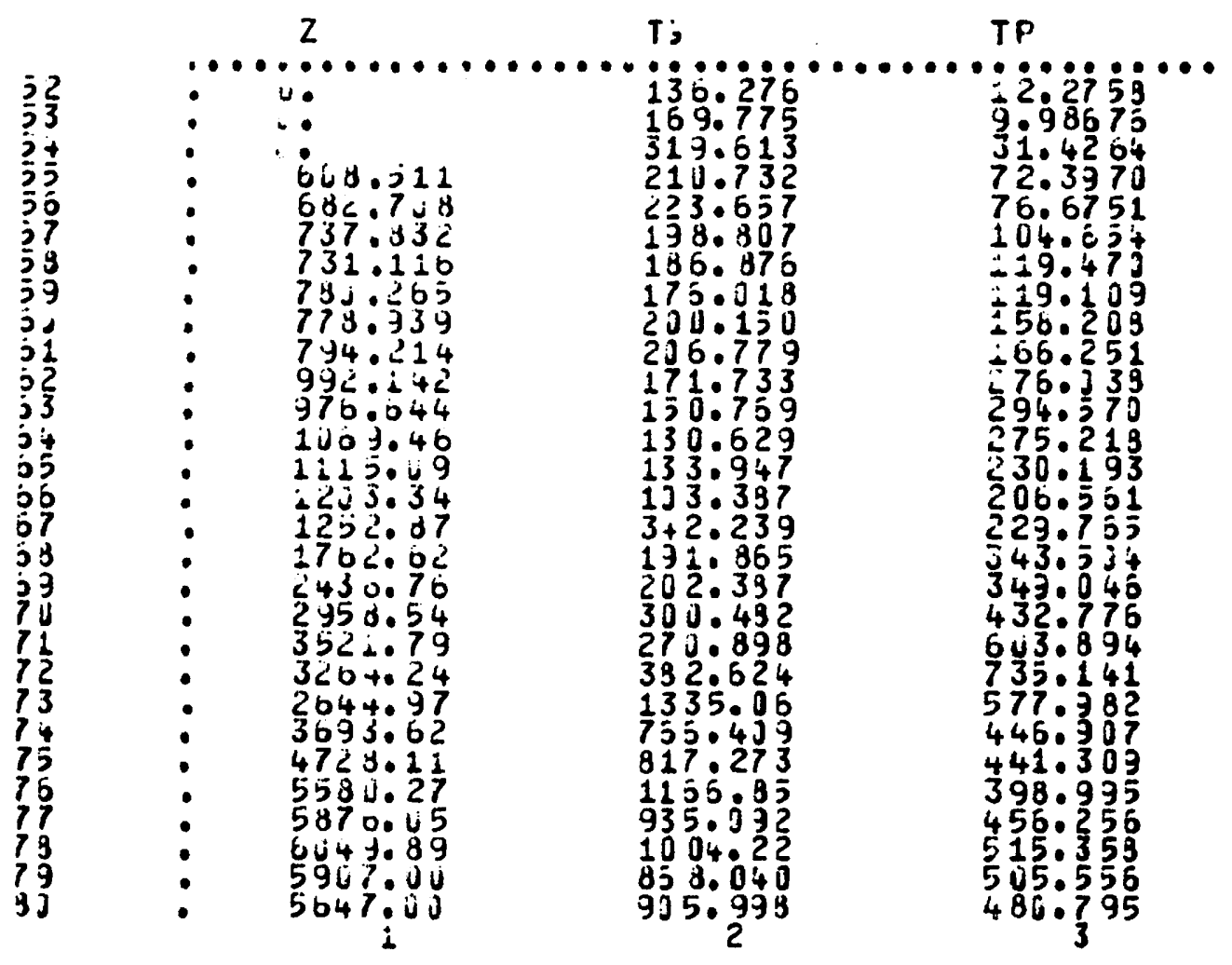


NOTES TO TABLE 1

GDP: $\quad$ Gross domestic product in 1975 shekels.

I: $\quad$ Gross domestic capital formation in 1975 shekels.

P: $\quad$ GDP deflator, base 1975.

E: Effective exchange rate on exports of goods and services.

Calculated by adding to the formal exchange rate the subsidies

per dollar of exports.

ZN: Israel's end-of-year net foreign liabilities in millions of

dollars. Calculated as follows: Government and Bank of Israel

debt plus foreign deposits in domestic banks and other private debt

minus (foreign reserves at the Bank of Israel and other monetary

institutions plus deposits with banks abroad and other assets and foreign liabilities).

TGN, TPN: Unilateral transfers to the public and private sectors respectively, in millions of dollars.

$Z=Z N \cdot E / P, T G=T G N \cdot E / P, T P=T P N \cdot E / P$.

SOURCES: The series GDP, I, G (below) P, and $Z N$ from the Statistical Abstract of Israel 1982, Central Bureau of Statistics. The TGN, TPN, and E from the Bank of Israel's Research Department data and the Annual Reports 1980 and 1981. 
TABLE 2

$Y$

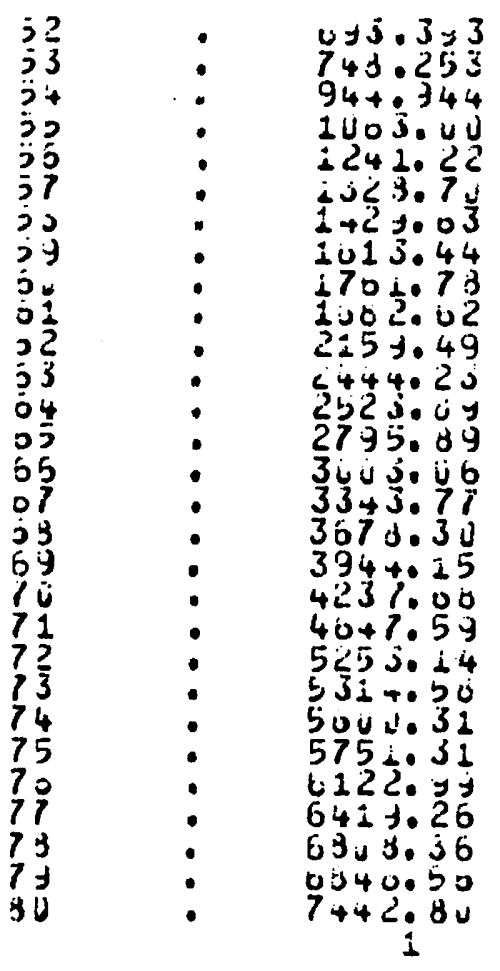

G

g

$\xi$

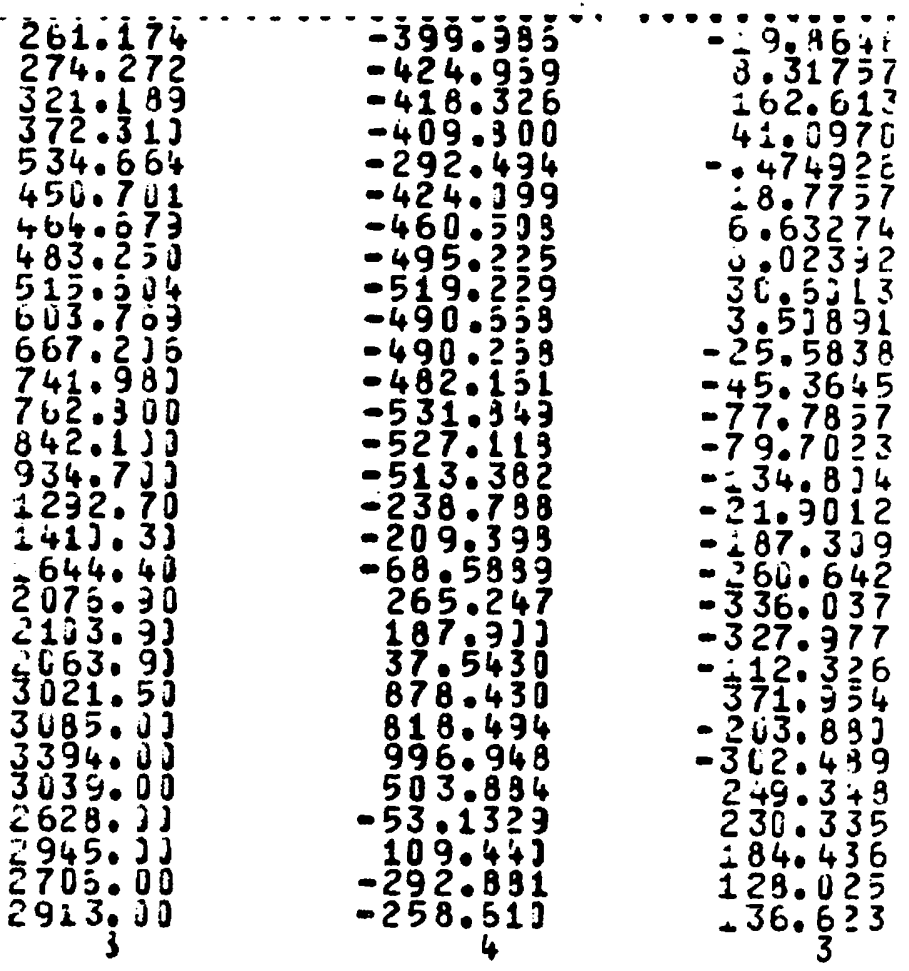


NOTES TO TABLE 2

$Y \equiv G D P+T P-I . \quad y$ is the residual calculated from equation (15'). (See below).

G: General government consumption expenditure in 1975 shekels. It includes all defense expenditures.

g: the residual calculated from equation (14').

$\xi$ : the residual calculated from equation (16').

A distinct characteristic of the $y$ series (and also of the $g$ series to a lesser extent) is that it is mostly negative, with strongly negative values in the first part of the sample. Just by looking at the series one can conclude that if OLS would have been used to estimate the trend values of $Y$, the resulting growth rate estimate $\hat{\mu}$ would have been higher (and correspondingly $\hat{a}$ lower) than that reported in the text. This difference can be interpreted as follows. In the first period of the sample $n_{1}=p n_{0}+\tilde{n}_{1}$. Assume that the sample starts off with $n_{0}<0$, i.e.,. with a negative deviation from the normal $Y$ values -- as seems natural in the early years of the state. Then, aside from new zero-mean disturbances, the value of $n_{t}$ will become less negative over time. This means that $n_{t}$ is positively correlated with time, which is the only OLS explanatory variable. Consequently the OLS estimate of $\mu$ is biased upwards. This bias disappears when the equation is transformed to deal with the serial correlation. Then the error term of the equation is $\tilde{n}_{t}$, which is white noise. 
$8101 C$

$8102 C$

$8103 C$

$8104 \mathrm{C}$

$8105 \mathrm{C}$

$8106 C$

$8107 C$

8108C D S

81.09 C D SU

$8110 \mathrm{C}$

$8111 C$

82016

$8202 C$

$8203 C$

$8204 C$

$8205 C$

$8206 C$

$8207 C$

$8208 C$

8209C DSU

Markusen, James R. Factor Movements and Commodity Trade as Compliments: A Survey of Some Cases.

Conlon, R.M. Comparison of Australian and Canadian Manufacturing Industries: Some Empirical Evidence.

Conlon, R.M. The Incidence of Transport Cost and Tariff Protection: Some Australian Evidence.

Laidler, David. On the Case for Gradualism.

Wirick, Ronald G. Rational Expectations and Rational

Stabilization Policy in an Open Economy

Mansur, Ahsan and John Whalley Numerical Specification of Applied

General Equilibrium Models: Estimation, Calibration, and Data.

Burgess, David F., Energy Prices, Capital Formation, and Potential GNP Jimenez, E. and Douglas H Keare. Housing Consumption and Income in the Low Income Urban Setting: Estimates from Panel Data in El Salvador

Whalley, John Labour Migration and the North-South Debate

Manning, Richard and John McMillan Government Expenditure and Comparative Advantage

Freid, Joel and Peter kowitt Why Inflation Reduces Real Interest Rates

$\underline{1982}$

Manning, Richard and James R. Markusen Dynamic Non-Substitution and Long Run Production Possibilities

Feenstra, Robert and Ken Judd Tariffs, Technology Transfer, and Welfare

Ronald $W$. Jones, and Douglas D. Purvis: International Differences in Response to Common External hocks: The Role of Purchasing Power Parity

James A Brander and Barbara J. Spencer: Industrial strategy with Committed Firms

Whalley, John, The North-South Debate and the Terms of Trade: An Applied General Equilibrium Approach

Roger Betancourt, Christopher Clague, Arvind Panagariya CAPI TAL UTI LI ZATI ON IN GENERAL EOUIIIBRI UM

Mansur, Ahsan $H$ On the Estimation of Import and Export Demand Elasticities and Elasticity Pessimism.

Whalley, J. and Randy Wigle PRICE AND QUANTITY RIGIDITIES IN ADJUSTMENT TO TRADE POLICY CHANGES: ALTERNATIVE FORMULATIONS AND INITIAL CALCULATIONS

Jimenez, E. SQUATTING AND COMMUNITY ORGANIZATION IN DEVELOPING COUNTRIES: A CONCEPTUAL FRAMEWORK 
8210C Grossman, G.M. INTERNATIONAL COMPETITION AND THE UNIONIZED SECTOR

8211C LaIdler,D. FRIEDMAN AND SCHWARTZ ON MONETARY TRENDS - A REVIEW ARTICLE

8212C Imam, M.H. and Whalley, J. INCIDENCE ANALYSIS OF A SECTOR SPECIFIC MINIMUM WAGE IN A TWO SECTOR HARRIS-TODARO MODEL.

$8213 \mathrm{C}$ Markusen, J.R. and Melvin, J.R. THE GAINS FROM TRADE THEOREM WITH INCREASING RETURNS TO SCALE. 8214C INDUSTRIAL ORGANIZATION AND THE GENERAL EQUILIBRIUM COSTS OF PROTECTION IN
SMALL OPEN ECONOMIES.

8215C Laldler, D. DID MACROECONOMICS NEED THE RATIONAL EXPECTATIONS REVOLUTION?

8216C Whalley, J. and Wigle, R. ARE DEVELOPED COUNTRY MULTILATERAL TARIFF REDUCTIONS NECESSARILY BENEFICIAL FOR THE U.S.?

8217C Bade, $R$. and Parkin, M. IS STERLING M3 THE RIGHT AGGREGATE?

$8218 \mathrm{C}$ Kosch, B. FIXED PRICE EQ̣UIIIBRIA IN OPEN ECONOMIES.

1983

8301C Kimbell, L.J. and Harrison, G.W. ON THE SOLUTION OF GENERAL EQUILIBRIUM

8302C Melvin, J.R. A GENERAL EQUILIBRIUM ANALYSIS OF'.CANADIAN OIL POLICY.

8303C Markusen, J.R. and Svensson, L.E.0. TRADE IN GOODS AND FACTORS WITH INTERNATIONAL DIFFERENCES IN TECHNOLOGY.

8304C Mohammad, S. Whalley, J. RENT SEEKING IN INDIA: ITS COSTS AND POLICY
SIGNIFICANCE.

8305C DSU Jimenez, E. TENURE SECURITY AND URBAN SỌUATTING. 8306C Parkin, M. WHAT CAN MACROECONOMIC THEORY TELL US ABOUT THE WAY DEFICITS
SHOULD BE MEASURED.

8307C Parkin, M. THE INFLATION DEBATE: AN ATTEMPT TO CLEAR THE AIR.

8308C Wooton, I. LABOUR MIGRATION IN A MODEL OF NORTH-SOUTH TRADE. 8309C Deardorff, A.V. THE DIRECTIONS OF DEVELOPING COUNTRIES TRADE: EXAMPLES
FROM PURE THEORY.

8310C Manning, R. ADVANTAGEOUS REALLOCATIONS AND MULTIPLE EQUILIBRIA: RESULTS FOR THE THREE-AGENT TRANSFER PROBLEM. 
$8311 \mathrm{C}$ DSU Mohammad, S. and Whalley, J. CONTROLS AND THE INTERSECTORAL TERMS OF TRADE IN INDIA.

8312C Brecher, Richard A. and Choudhri, Ehsan U. NEW PRODUCTS AND THE FACTOR CONTENT OF INTERNATIONAL TRADE.

8313C Jones, R.W., Neary, J.P. and Ruane, F.P. TWO-WAY CAPITAL FLOWS: CROSSHAULING IN A MODEL OF FOREIGN INVESTMENT.

$8314 \mathrm{C}$ DSU Follain, J.R. Jr. and Jimenez, E. THE DEMAND FOR.HOUSING CHARACTERISTICS IN DEVELOPING COUNTRIES.

8315C Shoven, J.B. and Whalley, J. APPLIED GENERAL EQUILIBRIUM MODELS OF TAXATION AND INTERNATIONAL TRADE.

8316C Boothe, Paul and Longworth David. SOME IRREGULAR REGULARITIES IN THE CANADIAN/U.S. EXCHANGE MARKET.

8317C Hamilton, Bob and Whalley, John. BORDER TAX ADJUSTMENTS AND U.S. TRADE.

8318C Neary, J. Peter, and Schweinberger, Albert G. FACTOR CONTENT FUNCTIONS AND THE THEORY OF INTERNATIONAL TRADE.

8319C Veall, Michael R. THE EXPENDITURE TAX AND PROGRESSIVITY.

8320C Melvin, James R. DOMESTIC EXCHANGE, TRANSPORTATION COSTS AND INTERNATIONAL TRADE.

8321C Hamilton, Bob and Whalley, John. GEOGRAPHICALLY DISCRIMINATORY TRADE ARRANGEMENTS .

8322C Bale, Harvey Jr. INVESTMENT FRICTIONS AND OPPORTUNITIES IN BILATERAL U.S.-CANADIAN TRADE RELATIONS.

$8323 \mathrm{C}$ Wonnacott, R.J. CANADA-U.S. ECONOMIC RELATIONS--A CANADIAN VIEW.

8324C Stern, Robert M. U.S.-CANADIAN TRADE AND INVESTMENT FRICTIONS: THE U.S. VIEN.

8325C Harrison, Glenn, H. and Kimbell, Larry, J. HOW ROBUST IS NUMERICAL GENERAL EQQUILIBRIUM ANALYSIS?

8326C Wonnacott, R.J. THE TASK FORCE PROPOSAL ON AUTO CONTENT: WOULD THIS SIMPLY EXTEND THE AUTO PACT, OR PUT IT AT SERIOUS RISK?

8327C Bradford, James C. CANADIAN DEFENCE TRADE WITH THE U.S. Conklin, David. SUBSIDY PACTS.

Rugman, Alan M. THE BEHAVIOUR OF U.S. SUBSIDARIES IN CANADA:

IMPLICATIONS FOR TRADE AND INVESTMENTS. 
8328C Boyer, Kenneth D. U.S.-CANADIAN TRANSPORTATION ISSUES.

8329C Bird, Richard M. and Brean, Donald J.S. CANADA-U.S. TAX RELATIONS: ISSUES AND PERSPECTIVES.

8330C Moroz, Andrew R. CANADA-UNITED STATES AUTOMOTIVE TRADE AND TRADE POLICY ISSUES.

8331C Grey, Rodney de C. and Curtis, John. INSTITUTIONAL ARRANGEMENTS FOR U.S.-CANADIAN NEGOTIATIONS. PART I: CANADA-U.S. TRADE AND ECONOMIC ISSUES: DO WE NEED A NEW INSTITUTION? PART II: INSTITUTIONAL ARRANGEMENTS FOR MANAGING THE CANADA-U.S. ECONOMIC RELATIONSHIP.

\section{4}

8401C Harrison, Glenn $W$. and Manning, Richard. BEST APPROXIMATE AGGREGATION OF INPUT-OUTPUT SYSTEMS.

840ं2C Parkin, Michael. CORE INFLATION: A REVIEW ESSAY.

8403C Blomqvist, Ake, and McMahon, Gary. SIMULATING COMMERICAL POLICY IN A SMALL, OPEN DUAL ECONOMY WITH URBAN UNEMPLOYMENT: A GENERAL EQUILIBRIUM APPROACH.

8404C Wonnacott, Ronald. THE THEORY OF TRADE DISCRIMINATION: THE MIRROR IMAGE OF VINERIAN PREFERENCE THEORY?

8405C Whalley, John. IMPACTS OF A 50\% TARIFF REDUCTION IN AN EIGHT-REGION GLOBAL TRADE MODEL.

8406C Harrison, Glenn W. A GENERAL EQUILIBRIUM ANALYSIS OF TARIFT REDUCTIONS.

8407C Horstmann, Ignatius and Markusen, James R. STRATEGIC INVESTMENTS AND THE DEVELOPMENT OF MULTINATIONALS.

8408C Gregory, Allan W. and McCurdy, Thomas H. TESTING THE UNBIASEDNESS HYPOTHESIS IN THE FORWARD FOREIGN EXCHANGE MARKET: A SPECIFICATION ANALYSIS.

8409C Jones, Ronald H. and Kierzkowski, Henryk. NEIGHBORHOOD PRODUCTION STRUCTURES WITH APPLICATIONS TO THE THEORY OF INTERNATIONAL TRADE.

8410C Weller, Paul and Yano, Makoto. THE ROLE OF FUTURES MARKETS IN INTERNATIONAL TRADE: A GENERAL EOUILIBRIUM APPROACH.

$8411 \mathrm{C}$ Brecher, Richard A. and Bhagwati, Jagdish N. VOLUNTARY EXPORT RESTRICTIONS VERSUS IMPORT RESTRICTIONS: A WELFARE-THEORETIC COMPARISON. 
8412C Ethier, Wilfred J. ILLEGAL IMMIGRATION.

8413C Eaton, Jonathon and Gene M. Grossman. OPTIMAL TRADE AND INDUSTRIAL POLICY UNDER OLIGOPOLY.

8414C Wooton, Ian. PREFERENTIAL TRADING AGREEMENTS - A 3xn MODEL.

8415C Parkin, Michael. DISCRIMINATJNG BETWEEN KEYNESIAN AND

CLASSICAL THEORIES OF THE BUSINESS CYCLE; JAPAN 1967-1982

8416C Deardorff, Alan V. FIRless FIRwoes: HOW PREFERENCES CAN INTERFERE WITH THE THEOREMS OF INTERNATIONAL TRADE.

8417C Greenwood, Jeremy. NONTRADED GOODS, THE TRADE BALANCE, AND THE BALANCE OF PAYMENTS.

8418C Blomqvist, Ake and Sharif Mohammad. CONTROLS, CORRUPTION, AND COMPETITIVE RENT-SEEKING IN LDCS.

8419C Grossman, Herschel I. POLICY, RATIONAL EXPECTATIONS, AND POSITIVE ECONOMIC ANALYSIS.

8420C Garber, Peter M. and Robert G. King. DEEP STRUCTURAL EXCAVATION? A CRITIOUUE OF EULER EQUATION METHODS.

8421C Barro, Robert J. THE BEHAVIOR OF U.S. DEFICITS.

8422C Persson, Torsten and Lars E.0. Svensson. INTERNATIONAL BORROWING AND TIME-CONSISTENT FISCAL POLICY.

8423C Obstfeld Maurice. CAPITAL CONTROLS, THE DUAL EXCHANGE RATE, AND DEVALUATION.

8424C Kuhn, Peter. UNION PRODUCTIVITY EFFECTS AND ECONOMIC EFFICIENCY.

8425C Hamilton, Bob and John Whalley. TAX TREATMENT OF HOUSING IN A DYNAMIC SEOQUENCED GENERAL EOUILIBRIUM MODEL.

\$426C Hamilton, Bob, Sharif Mohammad, and John Whalley. RENT SEEKING AND THE NORTH-SOUTH TERMS OF TRADE.

8427C Adams, Charles and Jeremy Greenwood. DUAL EXCHANGE RATE SYSTEMS AND CAPITAL CONTROLS: AN INVESTIGATION.

8428 Loh, Choon Cheong and Michael R. Veall. A NOTE ON SOCIAL SECURITY AND PRIVATE SAVINGS IN SINGAPORE.

8429 Whalley, John. REGRESSION OR PROGRESSION: THE TAXING OUESTION OF INCIDENCE ANALYSIS.

8430 Kuhn, Peter. WAGES, EFFORT, AND INCENTIVE-COMPATIBILITY IN LIFE-CYCLE EMPLOYMENT CONTRACTS. 
8431 Greenwood, Jeremy and Kent P. Kimbrough. AN INVESTIGATION IN THE THEORY OF FOREIGN EXCHANGE CONTROLS.

8432 Greenwood, Jeremy and Kent P. Kimbrough. CAPITAL CONTROLS AND THE INTERNATIONAL TRANSMISSION OF FISCAL POLICY.

8433 Nguyen, Trien Trien and John Whalley. EỌILIBRIUM UNDER PRICE CONTROLS WITH ENDOGENOUS TRANSACTIONS COSTS.

8434 Adams, Charles and Russell S. Boyer. EFFICIENCY AND A SIMPLE MODEL OF EXCHANGE RATE DETERMINATION.

8435 Kuhn, Peter. UNIONS, ENTREPRENEURSHIP, AND EFFICIENCY.

8436 Hercowitz, Zvi and Efraim Sadka. ON OPTIMAL CURRENCY. SUBSTITUTION POLICY AND PUBLIC FINANCE.

8437 Lenjosek, Gordon and John Whalley. POLICY EVALUATION IN A SMALL OPEN PRICE TAKING ECONOMY: CANADIAN ENERGY POLICIES.

8438 Aschauer, David and Jeremy Greenwood. MACROECONOMIC EFFECTS OF FISCAL POLICY.

8439C Hercowitz, Zvi. ON THE DETERMINATION OF THE EXTERNAL DEBT: THE CASE OF ISRAEL. 